\title{
SALAT SEBAGAI BASIS PENDIDIKAN AGAMA ISLAM: ANALISIS TEORI CLIFFORT GEERTZ
}

\author{
Ahmad Riyadh Maulidi \\ Pendidikan Agama Islam, Fakultas Tarbiyah dan Keguruan, \\ Universitas Islam Negeri Antasari Banjarmasin \\ J1. Tidar Raya 1 Gg. Dahlia, No. 312, Sampit, 74312 \\ ahmadriyadhmaulidi312@gmail.com
}

\begin{abstract}
Abstrak: Salat lima waktu merupakan ibadah yang utama dalam Islam. Banyak kemuliaan dan keistimewaan dalam ibadah ini. Perintah wajib dan dilakukan sebanyak lima kali dalam semalam menjadikan salat sebagai ibadah yang sudah melekat di hati umat Islam. Bagi umat Islam yang beriman dan bertakwa, selain dihinggapi perasaan berdosa, meninggalkan salat juga menjadikan pelakunya menjadi tidak tenang. Sehingga dari sini secara tidak langsung salat sudah memberikan manfaat positif bagi siapa yang menjalankannya. Inilah yang dinamakan dengan pendidikan. Cliffort Geertz dengan teorinya Agama sebagai Budaya menempatkan ibadah salat sebagai simbol-simbol sakral yang akan memengaruhi proses sosial atau budaya. Proses sosial atau budaya inilah yang akan menjadi basis pendidikan agama bagi umat Islam dan tentu dengan sebuah pendidikan akan mengubah hasil budi daya seseorang, khususnya seorang muslim bahkan umat Islam. Hal ini menarik bagi peneliti untuk mencari titik temu antara kewajiban ibadah salat tersebut dengan teori yang dipaparkan oleh Geertz. Sehingga hal ini menjadi hal yang perlu untuk dianalisis lebih dalam. Metode penelitian ini menggunakan metode kepustakaan dengan mencari sumber-sumber yang membahas masalah salat dan teori Cliffort Geertz.
\end{abstract}

\begin{abstract}
Prayer As a Basis for Islamic Education: an Analysis of The Theory of Cliffort Geertz: The five daily prayers are the main worship in Islam. Lots of glory and privilege in this worship. Mandatory orders and carried out five times a day make prayer as a worship that is inherent in the hearts of Muslims. For the faithful and pious Muslims, besides being infested with feelings of sin, leaving the prayers also makes the perpetrators uneasy. So that indirectly prayer has provided positive benefits for those who carry it out. This is what is called education. Cliffort Geertz with his theory of Religion as Culture places the prayer as sacred symbols that will influence social or cultural processes. This social or cultural process will be the basis of religious education for Muslims and certainly with an education will change the results of one's cultivation, especially a Muslim and even Muslims. This is interesting for researchers to look for a meeting point between the obligations of the prayer with the theory presented by Geertz. So this is something that needs to be analyzed more deeply. This research method uses the literature method by searching for sources that discuss the issue of prayer and Cliffort Geertz's theory.
\end{abstract}

Kata Kunci : Salat, Pendidikan, Cliffort Geertz, Agama, Budaya 


\section{Pendahuluan}

Salat merupakan ibadah yang utama dalam Islam. Ibadah ini memberi peran penting dalam kehidupan, baik untuk kehidupan dunia, terlebih-lebih lagi untuk kehidupan akhirat. Karena urgennya ibadah ini, umat Islam pun diwajibkan oleh Allah Swt. untuk melaksanakannya lima kali dalam sehari semalam. Ketika ibadah ini dilakukan sesuai dengan rukun dan syaratnya, ditambah lagi dengan keikhlasan dan kekhusyukan, tentu ibadah ini akan memberi manfaat yang besar bagi yang melaksanakannya.

Saking pentingnya ibadah salat ini, sampai-sampai Nabi Muhammad Saw. menjadikan salat sebagai pembeda antara orang mukmin dan orang kafir. Ketika salat djadikan sebagai pembeda atau pembatas, tentu akan membedakan antara yang dibatasi dan akan mengeluarkannya dari yang lain. Secara tidak langsung, jika ada seorag muslim yang meninggalkan salat, maka ia pun menghilangkan statusnya sebagai muslim.

Salat secara etimologi berasal dari bahasa Arab الصَّلاةُ yang berarti doa. Adapun secara istilah, salat ialah ibadah yang tersusun dari beberapa perkataan dan perbuatan yang diawali dengan takbir dan diakhiri dengan salam serta memenuhi syarat yang ditentukan. ${ }^{1}$ Salat termasuk ibadah mahdah, yakni ibadah yang cara dan ketentuanya telah ditentukan oleh Allah Swt. Perintah salat ini pun langsung diterima oleh Nabi Muhammad Saw. dari Allah Swt. pada malam isra mi'raj. Diterimanya perintah salat secara langsung, dan tidak melalui perantara malaikat Jibril ini menunjukkan bahwa salat merupakan ibadah yang sangat istimewa.

Dengan segala keistimewaannya, tentu banyak manfaat yang didapat dari ibadah salat, manfaat tersebut ialah: 1) salat adalah ibadah yang dapat mencegah manusia dari perbuatan buruk, 2) salat sebagai sumber petunjuk, 3) salat sebagai sarana meminta pertolongan dari Allah Swt., 4) salat sebagai pelipur jiwa, 5) salat dapat mendatangkan kebahagiaan dan daya kreatifitas dan 6) salat sebagai sarana dalam menjaga kesehatan jiwa yang nantinya akan berpengaruh terhadap kesehatan tubuh. Dari berbagai manfaat salat tersebut dapat diketahui bahwasanya di samping fungsi utamanya sebagai sarana beribadah kepada Allah Swt., ibadah salat juga akan memperhalus akhlak bagi yang mengerjakannya sehingga kualitas hidupnya akan meningkat. ${ }^{2}$

Di samping berbagai manfaat yang didapat ketika seseorang melaksanakan salat, salat juga menjadi penetu diterimanya amal seseorang atau tidak. Hal ini terlihat dalam hadis Nabi Muhammad Saw. riwayat Ibnu Majah yang menyatakan barang siapa yang amal ibadah salatnya rusak (tidak diterima), maka rusaklah seluruh amalnya yang lain. Tetapi sebaliknya, jika amal ibadah salatnya bagus (diterima), maka baguslah seluruh amalnya yang lain.

\footnotetext{
${ }^{1}$ Sulaiman Rasjid, Fiqh Islam: Hukum Fiqh Lengkap, (Bandung: Sinar Baru Algensindo, 2001), h. 53 .

${ }^{2}$ Haidar Bagir, Buat Apa Sahalat?! Kecuali Jika Anda Hendak Mendapatkan Kebahagiaan dan Ketenangan Hidup, (Bandung: Mizania, 2007), h. 27.
} 
Segala keutamaan yang ada pada salat tersebut tidak serta merta didapatkan oleh semua orang. Tentu hanya orang-orang yang mengerjakan dengan sungguh-sungguhlah yang akan mendapatkan keutamaan dari salat tersebut. Bukan hanya sekedar menggugurkan kewajiban agar dilihat sebagai orang muslim, melainkan memang merasa perlu dan merasa tidak nyaman jika ia meninggalkan salat. Bukan hanya menganggap salat sebagai ritual keagamaan belaka, namun lebih dari itu salat sebagai media komunikasi antara hamba dengan Sang Pencipta. Ketika salat ini dilaksanakan dengan segala kekhsuyukan dan kesngguhan, maka pasti akan berpengaruh dengan kehidupan orang yang menjalankannya. Terlebih lagi salat ini dilaksanakan selama lima kali dalam sehari. Maka ibadah ini akan menjadi kebiasaan. Kebiasaan yang bersumber dari agama inilah yang menurut Cliffort Geertz dapat berkembang sebagai sikap terhadap kehidupan atau dikenal dengan istilah budaya.

\section{Biografi Singkat dan Pemikiran Cliffort Geertz}

Cliffort Geertz lahir di San Fransisco, California pada tahun 1926 dan meninggal dunia pada 31 Oktober 2006. ${ }^{3}$ Setelah menyelesaikan SMA, ia mendapat pendidikan perguruan tinggi gratis di Antoch, Ohio dan mendapat gelar B.A di tahun 1950. Kemudian ia melanjutkan studinya di Harvard University pada jurusan studi antropologi. Selama di Harvard inilah ia banyak melakukan penelitian lapangan tentang masyarakat multi agama di Indonesia, khususnya Jawa. ${ }^{4}$ Penelitiannya inilah yang nantinya akan mengantarkan Geertz untuk menyandang gelar Ph.D pada tahun 1956. Setelah lulus, ia kemudian melakukan penelitian yang kedua kalinya di Indonesia, yakni Bali hingga tahun $1970 .^{5}$

Pendidikan formal yang Geertz tempuh inilah yang melatarbelakangi keilmuan ia pada bidang antropologi. Geertz dalam Schilbrack mendefinisikan agama sebagai $a$ system of symbols that functions to unite a certain way of life. Agama merupakan sistem dari simbol yang berfungsi untuk menyatukan cara hidup. Sehingga dengan agama inilah maka didapat cara hidup yang ideal. ${ }^{6}$ Maksudnya ialah agama yang disebut dengan simbol-simbol sakral tersebut akan mensintesiskan suatu etos, baik nada, ciri, kualitas kehidupan, moral, gaya etis, suasana hati dan pandangan, yang mana semua itu merupakan cara hidup yang ideal yang telah disesuaikan dengan permasalahan aktual.

Cara hidup inilah yang disebut dengan budaya, yakni berupa pola-pola makna yang diteruskan secara historis yang dengannya manusia dapat berkomunikasi, melestarikan dan mengembangkan pengetahuan tentang kehidupan. ${ }^{7}$ Sehingga pada akhirnya akan didapat interkoneksi antara keyakinan dan tindakan. Misalnya simbolsimbol Islam yang mampu berperan di luar ranah kognitif. ${ }^{8}$

\footnotetext{
${ }^{3}$ Mahli Zainudin Tago, “Agama dan Integrasi Sosial dalam Pemikiran Clifford Geertz,” Jurnal Kalam VII, no. 1, (2013): h. 81.

${ }^{4}$ Richard A Schweder dan Byron Good, Clifford Geertz by His Colleagues, (London: The University of Chicago Press, 2005), h. 58.

5 Seth D Kunin dan Jonathan Miles-Watson, Theories of Religion: A Reader, (New Jersey: Rutgers University Press, 2006), h. 207.

${ }^{6}$ Kevin Schilbrack, Thinking Through Rituals: Philosophical Perspectives, (New York and London: Routledge, 2004), h. 128.

${ }^{7}$ Michael Banton, Anthropological Approaches to The Study of Religion, (London: Tavistock Publications, 2004), h. 3.

${ }^{8}$ David E Apter, "Clifford Geertz As a Cultural System”, Journal Cultural Sosiology V, no. 175, (2011): h. 189.
} 
Makna yang terkandung dalam simbol suatu agama akan terkait dengan struktur sosial dan proses-proses psikologis. Kepercayaan-kepercayaan religius akan melahirkan proses sosial. Sehingga pada akhirnya agama akan membentuk suatu sistem budaya. ${ }^{9}$ Dalam perspektif sosiologis, terdapat hubungan interdependensi antara agama dan proses sosial masyarakat, di mana keduanya saling memengaruhi satu sama lain. Agama akan berpengaruh terhadap proses sosial masyarakat dan proses sosial masyarakat tersebut juga akan berpengaruh terhadap agama. ${ }^{10}$ Begitu juga dengan perihal agama, yakni salat. Jika dilihat dari perspektif teori Cliffort Geertz, tentu salat sebagai bentuk simbol agama akan memberi pengaruh terhadap proses sosial masyarakat, khususnya pendidikan.

\section{Salat sebagai Ibadah yang Membudaya}

Perintah salat lima waktu diterima oleh Nabi Muhammad Saw. saat peristiwa isra mi'raj. Berkenaan dengan hal tersebut, dalamm kitab Fiqh Al-Sirah karangan Muhammad Al-Ghazali yang dikutip oleh Ahmad Rofi Usmani menyatakan "Pada saat mi'raj itulah Rasulullah Saw. menerima perintah Allah Swt. tentang salat fardu lima kali sehari semalam. Ketentuan itu ditetapkan di langit supaya salat menjadi mi raj yang dapat mengangkat martabat manusia menjadi lebih tinggi". ${ }^{11}$ Dari pernyataan ini tentu terlihat bahwa ibadah salat ini akan menjadikan umat Islam yang menjalankannya pada kedudukan yang lebih tinggi. Terlebih lagi salat ini dilakukan lima kali dalam sehari. Tentu dapat dibayangkan betapa banyak kemuliaan yang didapat jika ibadah ini dilakukan dengan sungguh-sungguh.

Salat yang dilakukan secara berulang-ulang dengan khusyuk dan penuh konsentrasi akan melahirkan kondisi psikologis yang positif bagi kejiwaan. Ketika bacaan salat tersebut dilisankan dengan penjiwaan yang tinggi, maka akan melatih tiga hal penting dalam diri manusia, yakni kecerdasan intelektual, emosional dan spiritual. Dengan kesungguhan dan kehusyukan tadi lah maka kesimbangan tubuh dapat benarbenar terwujud serta dapat berpengaruh terhadap tingkat konsentrasi pikiran untuk mengerjakan seluruh aktivitas dalam kehidupan sehari-hari. ${ }^{12}$

Dalam teori budaya, ada hubungan erat yang terjadi antara otak dan aktivitas yang dilakukan secara terus menerus. Budaya merupakan serangkaian yang aktivitas yang dapat membentuk otak. Manusia menjadi berbudaya melalui pelatihan dalam berbagai aktivitas, seperti adat-kebiasaan, kesenian, cara-cara berinteraksi dengan masyarakat, penggunaan teknologi bahkan ketika belajar ide-ide, kepercayaan, filosofi yang dipahami bersama serta agama. ${ }^{13}$ Salah satu unsur yang disebutkan dalam aktivitas tersebut ialah agama. Agama menjadi aktivitas yang membudaya karena kegiatan agama memang dilakukan secara terus-menerus seiring dengan kebutuhan dan kewajiban manusia akan agama. Berdasar temuan riset neuroplastis, kegiatan yang dilakukan secara terus-menerus akan membentuk otak manusia. Terlebih lagi dalam hal

${ }^{9}$ Clifford Geertz, The Interpretation of Cultures, (London: Basic Books, 1974), h. -.

10 Tago, "Agama dan Integrasi..., h. 82-83.

11 Ahmad Rofi Usmani, Kisah Para Pencari Nikmatnya Shalat, (Bandung: Mizan Pustaka, 2015), h. 14.

${ }^{12}$ Madto Wratsangko ,Shalat Jadi Obat, (Jakarta: Elex Media Komputindo, 2010), h. 5.

13 M. Dwi Marianto, Seni dan Daya Hidup dalam Perspektif Quantum, (Yogyakarta: Scritto Boks, 2019), h. 228. 
salat. Sehingga jika salat ini dikerjakan dengan sungguh-sungguh dan dalam waktu sehari semalam, maka akan terjadi perubahan-perubahan baru pada otak. Maka patutlah dikatakan bahwa salat memang ibadah yang membudaya. Dilakukan secara terusmenerus yang dengan itu dapat merangsang pemikiran ke arah yang positif. Pada akhirnya nanti akan membawa pengaruh baik dalam kehidupan seseorang dan inilah yang disebut dengan pendidikan.

Ketika ibadah salat lima waktu ini hadir sebagai ibadah dengan segala keistimewaan dan kemuliaannya, tentu akan banyak memberi pengaruh positif bagi yang menjalankannya. Menurut sebuah riset, ibadah salat lima waktu juga memberi pengaruh terhadap etos kerja. Jika pelaksanaan salat ini dilakukan dengan baik, maka etos kerja pun akan membaik yang nantinya akan berdampak pada produktivitas kerja, begitu juga sebaliknya. ${ }^{14}$ Begitu juga dalam penelitian yang dilakukan oleh Munawir. Dalam tesisnya tersebut terlihat bahwa ada pengaruh positif yang signifikan antara pelaksanaan ibadah salat terhadap akhlak peserta didik di SDIT Fitrah Insani Langkapura Bandar Lampung. ${ }^{15}$ Hal ini selaras dengan penelitian yang dilakukan oleh Arif Rahman Hakim di SMPN 3 Ciputat Tangerang, menyatakan bahwa terdapat pengaruh positif yang signifikan antara pelaksanaan ibadah salat terhadap akhlak peserta didik di sekolah tersebut. Ketika ibadah salat dilaksanakan, khususnya salat lima waktu, maka akan memberi pengaruh terhadap akhlak peserta didiknya. ${ }^{16}$

Beberapa penelitian di atas menggambarkan bahwa ketika ibadah salat itu dilaksankan secara terus menerus dan dilakukan dengan sungguh-sungguh, maka akan terbentuk budaya salat. Ibadah tersebut dijadikan sebagai budaya yang memang dilakukan secara terus menerus. Akibatnya ialah muncul pengaruh yang baik dalam kehidupan seseorang. Sehingga memang nilai-nilai agama inilah yang nantinya akan membentuk suatu sistem, yang mana dengan sistem itu akan tercipta kondisi sosial yang baik.

\section{Salat dan Teori Cliffort Geertz}

Agama mempunyai peran penting dalam konteks budaya dan dinamika kehidupan masyarakat. Oleh karenanya, menurut Cliffort Geertz yang namanya beragama tentu si hamba dengan segala ajarannya tersebut harus mampu mengubah suatu tatanan masyarakat. Hal inilah yang dalam teori Geertz disebut dengan modes for reality atau dengan kata lain adanya eksistensi agama sebagai suatu sistem yang dapat membentuk masyarakat. ${ }^{17}$ Begitu juga dalam hal salat lima waktu dalam ajaran Islam. Sebagai ibadah yang berasal dari agama, maka sudah seharusnya salat ini mengubah tatanan perilaku kehidupan masyarakat. Sehingga antara salat dan budaya akan membentuk suatu sistem.

${ }^{14}$ Lailatul Qodar, dkk., "Pelaksanaan Ibadah Sholat dan Pengaruhnya Terhadap Etos Kerja", Jurnal Studi Agama I, no. 1, (2017): h. 11.

${ }^{15}$ Munawir, "Pengaruh Pelaksanaan Ibadah Shalat Terhadap Akhlak Siswa SDIT Fitrah Insani Langkapura”, (Tesis S2 Program Pasca Sarjana Studi Ilmu Tarbiyah Universitas Islam Negeri Raden Intan Lampung, 2017), h. 76.

16 Arif Rahman Hakim, "Pengaruh Pelaksanaan Ibadah Shalat Terhadap Akhlak Siswa di SMPN 3 Ciputat-Tangerang”, (Skripsi S1 Fakultas Ilmu Tarbiyah dan Keguruan Universitas Islam Negeri Syarif Hidayatullah Jakarta, 2008), h. 70.

17 Wahyuni, Agama dan Pembentukan Struktur Sosial, (Jakarta: Prenadamedia Group, 2018), h. 120. 
Salat yang dilakukan secara terus menerus akan lahir sebagai budaya. Ketika lahir budaya disiplin dalam salat, baik berupa pemenuhan syarat dan rukunnya terlebih lagi mampu menghasilkan penghayatan yang tinggi terhadap Tuhannya, maka hal ini akan membawa si hamba tersebut kepada sebuah sistem budaya yang lebih luas. Berawal dari keistimewaan salat yang didapatkan oleh seseorang muslim, pada akhirnya keistimewaan ini berdampak pula pada umat muslim secara umum. Misalnya saja salat mendidik kesatuan dan persatuan umat. Orang yang salat sudah pasti menghadap ke satu tempat yang sama, yakni Baitullah. Perasaan persatuan ini akan menimbulkan saling pengertian dan saling melengkapi antarsesama. ${ }^{18}$ Dari sinilah akan terbentuk budaya yang baik dalam komunitas tersebut. Budaya yang baik ini nantinya akan memberi kesan bahwa umat muslim tersebut merupakan kaum terdidik. Terdidik dalam artian mereka telah dididik oleh pendidikan yang mereka dapatkan dalam ibadah salat.

Hal ini sangatlah sejalan dengan pendapat Geertz yang menyatakan bahwa agama merupakan simbol-simbol sakral yang berfungsi untuk mensintesiskan suatu etos bangsa, baik nada, ciri, kualitas kehidupan, moral, gaya etis, suasana hati dan pandangan. Semua unsur-unsur ini merupakan suatu pandangan atau cara bertindak bahkan dapat disebut juga dengan gagasan. Salat sebagai simbol-simbol yang sakral tentu juga memiliki fungsi yang sama dalam mensintesiskan unsur-unsur tersebut. Sehingga dengan ibadah salat tersebut maka akan didapat cara hidup yang ideal. Dengan cara hidup yang ideal ini tentu akan membuat hati siapa saja menjadi tenteram. Maka sesungguhya dari hal ini pun secara tidak angsung merupakan sebuah pendidikan. Hal ini sudah termaktub dalam Alquran surah Taha ayat 14 sebagai berikut.

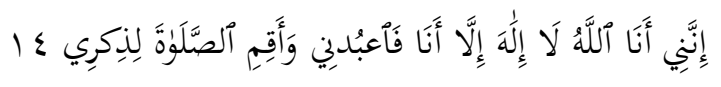

Artinya: Sesungguhnya Aku ini adalah Allah, tidak ada Tuhan (yang hak) selain Aku, maka sembahlah Aku dan dirikanlah shalat untuk mengingat Aku.

Ketika sudah mengingat Allah Swt. tentu hati seseorang akan menjadi tenteram, Allah Swt. berfirman sebagai berikut.

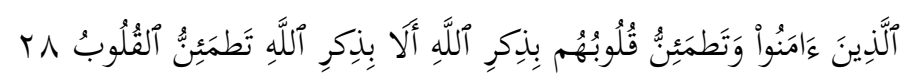

Artinya: (yaitu) orang-orang yang beriman dan hati mereka manjadi tenteram dengan mengingat Allah. Ingatlah, hanya dengan mengingati Allah-lah hati menjadi tenteram (Q.S. al-Ra'd: 28)

\section{Salat: Budaya dan Pendidikan}

Salat lima waktu merupakan ibadah wajib bagi setiap muslim. Saking wajibnya, sampai-sampai tidak alasan untuk meninggalkan salat. Bayangkan saja, orang yang sakit pun harus tetap melaksanakan salat walaupun dalam keadaan berbaring. Begitu juga dengan orang yang dalam perjalanan, harus tetap melaksanakan salat lima waktu yaitu dengan cara men-jamak atau meng-qasarnya atau bahkan kedua-duanya. Tidak adanya alasan untuk meninggalkan ibadah ini merupakan bukti bahwa ibadah salat lima waktu

18 Suharno, "Inilah Nilai-nilai Shalat," artikel diakses pada 12 Maret 2020 dari https://www.republika.co.id/berita/dunia-islam/hikmah/12/06/03/m50q76-inilah-nilainilai-shalat 
memang mempunyai rahasia-rahasia besar. Maksudnya banyak manfaat yang didapat jika seorang muslim melaksanakan salat. Manfaat tersebut baik untuk jasmani terlebihlebih lagi untuk rohani.

Seperti yang dijelaskan pada pembahasan sebelumnya, hanya orang-orang yang khusyuk dan sungguh-sungguhlah yang akan mendapatkan maanfaat itu. Sehingga ia nantinya akan merasakan dampak salat tersebut dalam hidupnya. Dengan kata lain, salat tersebut harus terlebih dulu menjadi budaya yang terus ia lakukan hingga memang ia cinta dan sangat butuh dengan ibadah salat ini. Dampak itulah yang nantinya akan ia rasakan sebagai pendidikan dalam hidupnya. Sebab, ia akan merasakan energi positif yang muncul sehingga berbagai perintah agama dapat ia laksanakan dan laranganlarangan agama dapat ia tinggalkan. Hal ini pun sangat erat kaitannya dengan akhlak atau karakter. Akhlak atau karakter inilah yang menjadi objek dalam pendidikan. Hal ini sesuai dengan tujuan pendidikan nasional yang terdapat dalam Undang-undang Nomor 20 Tahun 2003 tentang Sistem Pendidikan Nasional. Dalam Undang-undang tersebut dinyatakan bahwa Pendidikan adalah usaha sadar dan terencana untuk mewujudkan suasana belajar dan proses pembelajaran agar peserta didik secara aktif mengembangkan potensi dirinya untuk memiliki kekuatan spiritual keagamaan, pengendalian diri, kepribadian, kecerdasan, akhlak mulia, serta keterampilan yang diperlukan dirinya, kamu dan aku. Masyarakat bangsa dan negara.

Kekuatan spiritual keagamaan diletakkan lebih awal daripada potensi atau kemampuan yang lain. Hal ini menunjukkan bahwa betapa pentingnya kemampuan spiritual keagamaan atau yang disebut dengan karakter. Dalam hal ibadah, salat inilah yang nantinya akan memancarkan nilai pendidikan. Adapun nilai-nilai pendidikan yang terdapat dalam salat ialah:

\section{Pendidikan Kebersihan.}

Salat merupakan ibadah yang mempunyai makna sebagai sarana untuk menghubungkan hamba dengan Tuhannya. Ketika seorang hamba melakukan komunikasi tersebu, khususnya umat Islam, maka ia harus membersihkan dirinya terlebih dahulu. Baik jiwa maupun raganya. Hal ini dibuktikan dengan diperintahkannya umat Islam agar ikhlas dalam melaksanakan salat dan agar mensucikan dirinya terlebih dahulu sebelum menjalankan ibadah ini, baik dengan berwudu, mandi ataupun tayamum. Allah Swt. berfirman:

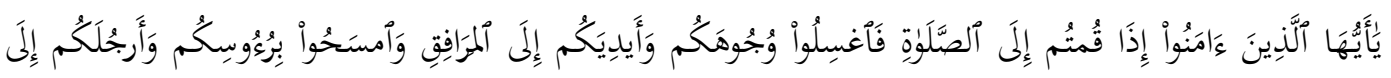

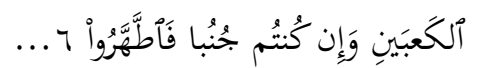

Artinya: Hai orang-orang yang beriman, apabila kamu hendak mengerjakan shalat, maka basuhlah mukamu dan tanganmu sampai dengan siku, dan sapulah kepalamu dan (basuh) kakimu sampai dengan kedua mata kaki, dan jika kamu junub maka mandilah... (Q.S. al-Ma'idah: 6)

\section{Pendidikan Menunaikan Hak Orang Lain}

Persoalan lain yang terkait dengan salat adalah masalah hak. Artinya, salat seorang muslim tidak akan diterima oleh Allah Swt. jika dalam salat itu ia mengambil hak orang lain. Artinya, seorang muslim harus memerhatikan apakah 
baju yang ia pakai ketika salat merupakan barang yang halal untuknya. Atau justru baju tersebut merupakan baju hasil curian atau baju yang dibeli dengan uang haram. Nabi Muhammad Saw. bersabda "Barangsiapa yang membeli pakaian dengan 10 dirham, satu dirham di antaranya adalah uang haram maka Allah tidak akan menerima salatnya selama pakaian itu dikenakannya."

\section{Pendidikan Disiplin Waktu}

Salat merupakan ibadah yang telah Allah Swt. tetapkan waktunya. Misalnya saja salat Subuh. Tidak sah salat Subuh yang dilakukan sebelum atau sesudah batas waktu itu. Hal ini membuat umat Islam terbiasa dan bisa mengatur waktunya sedemikian rupa.

\section{Pendidikan Persatuan}

Pendidikan persatuan terlihat dalam arah saat umat Islam salat. Arah tersebut ialah arah kiblat. Dalam hal ini, kewajiban menghadap ke satu arah kiblat dimaksudkan untuk menanakan pendidikan sosial di kalangan umat Islam. Sehingga tercipta rasa kebersamaan, kekompakan, satu arah dan tujuan.

\section{Pendidikan Menahan Diri}

Ibadah salat menghimpun berbagai hal untuk menahan diri atau hawa nafsu. Misalnya saja, dalam salat tidak diboehkan makan, minum dan tertawa atau berbicara dengan alasan apapun. Begitu juga dengan gerakan, seseorang yang salat harus berupaya menahan untuk tidak bergerak.

6. Pendidikan Ketenangan Jiwa dan Raga

Dalam salat, dilatih agar jiwa dan raga untuk tetap tenang. Gerakan dan bacaan yang dibaca saat salat pun dianjurkan untuk tidak dilakukan secara tergesa-gesa. Sehingga hal ini akan membawa kepada kekhusyukan.

7. Pendidikan Pemusatan Perhatian Hanya kepada Allah

Kalimat takbir yang dibaca ketika takbiratul ihram membuat orang yang salat benar-benar yakin bahwa segala kekuatan yang ada di dunia ini tidak ada apaapanya dibanding kekuatan Allah Swt. Kalimat tersebut mengandung arti bahwa Allah Swt. merupakan tuhan Yang Mahaagung, Mahatinggi dan Mahabesar.

\section{Pendidikan Keluarga}

Pendidikan keluarga yang terdapat dalam salat ialah dikarenakan kewajiban salat tidak hanya berlaku untuk diri sendiri. Terlebih lagi bagi kepala keluarga, ia pun harus bertanggung jawab agar keluarganya melaksanakan salat. Sehingga dari salat ini tentu ada sikap tanggung jawab dan sikap mendidik keluarga. ${ }^{19}$

${ }^{19}$ Afzalur Rahman dan Murtadha Muthahhari, Energi Salat: Gali Makna, Genggam Ketenangan Jiwa, (Jakarta: Serambi, 2007), h.83-98. 
Dari delapan unsur pendidikan tersebut sungguh terlihat jika salat lima waktu akan mendidik bagi siapa saja yang menjalankannya. Terlebih lagi bagi yang menjalankannya dengan sungguh-sungguh. Jika delapan unsur pendidikan tersebut sudah didapatkan maka fungsi salat lima waktu tersebut akan bermuara kepada mencegah perbuatan keji dan munkar. Allah Swt. berfirman sebagai berikut.

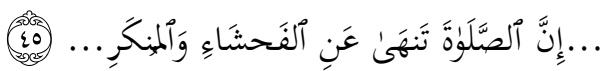

Artinya: ...Sesungguhnya shalat itu mencegah dari (perbuatan-perbuatan) keji dan mungkar... (Q.S. al-Ankabut: 45)

Jika seseorang sudah dapat mencegah dari perbuatan keji dan munkar, maka ia berhasil dalam mengarungi proses pendidikan tersebut. Bahkan hal ini dapat dijadikan sebagai basis pendidikan agama. Jika akhlaknya baik atau tidak pernah melakukan keji atau perbuatan dosa lainnya, maka ilmu akan mudah masuk. Sebab, ilmu itu bagaikan cahaya dan cahaya Allah Swt. tidak akan diberikan kepada orang yang bermaksiat.

\section{Penutup}

Ibadah salat lima waktu merupakan ibadah yang penuh dengan keistimewaan. Ketika ibadah yang dengan segala kemuliaannya ini dilaksanakan secara terus-menerus dan sungguh-sungguh maka akan menjadi budaya bagi yang umat Islam yang melaksanakannya. Dari pengalaman ibadah yang mulia ini, sudah pasti akan memancarkan energi positif, yakni ibadah salat itu akan mencegah pelakunya dari perbuatan keji dan munkar. Artinya ada nilai pendidikan yang didapatkan dalam ibadah salat lima waktu. Kemudian hal ini sesuai dengan teori yang dipaparkan oleh Cliffort Geertz mengenai agama sebagai suatu sistem budaya. Menurutnya, agama akan berpengaruh terhadap nilai-nilai budaya dalam dan begitu juga sebaliknya. Sehingga akan didapat korelasi antara agama yang dianut dan budaya yang dimiliki. Sama halnya dengan salat, semakin baik kualitas salat yang dilakukan oleh seorang muslim, maka semakin baik pula perilakunya dalam kehidupan sehari-hari. Perilaku inilah yang nantinya akan menjadi budaya.

\section{Daftar Pustaka}

Apter, David E. “Clifford Geertz As a Cultural System”, Journal Cultural Sosiology V, no. 175, (2011): h. 189.

Bagir, Haidar. Buat Apa Sahalat?! Kecuali Jika Anda Hendak Mendapatkan Kebahagiaan dan Ketenangan Hidup. Bandung: Mizania, 2007.

Banton, Michael. Anthropological Approaches to The Study of Religion. London: Tavistock Publications, 2004.

Geertz, Clifford. The Interpretation of Cultures. London: Basic Books, 1974.

Hakim, Arif Rahman. "Pengaruh Pelaksanaan Ibadah Shalat Terhadap Akhlak Siswa di SMPN 3 Ciputat-Tangerang." Skripsi S1 Fakultas Ilmu Tarbiyah dan Keguruan Universitas Islam Negeri Syarif Hidayatullah Jakarta, 2008.

Kunin, Seth D dan Jonathan Miles-Watson. Theories of Religion: A Reader. New Jersey: Rutgers University Press, 2006. 
Journal of Islamic Education Policy Vol. 4 No. 1 Januari - Juni 2019

Marianto M. Dwi. Seni dan Daya Hidup dalam Perspektif Quantum. Yogyakarta: Scritto Boks, 2019.

Munawir. "Pengaruh Pelaksanaan Ibadah Shalat Terhadap Akhlak Siswa SDIT Fitrah Insani Langkapura." Tesis S2 Program Pasca Sarjana Studi Ilmu Tarbiyah Universitas Islam Negeri Raden Intan Lampung, 2017.

Qodar, Lailatul. dkk., "Pelaksanaan Ibadah Sholat dan Pengaruhnya Terhadap Etos Kerja", Jurnal Studi Agama I, no. 1, (2017): h. 11.

Rahman, Afzalur dan Murtadha Muthahhari. Energi Salat: Gali Makna, Genggam Ketenangan Jiwa. Jakarta: Serambi, 2007.

Rasjid, Sulaiman. Fiqh Islam: Hukum Fiqh Lengkap. Bandung: Sinar Baru Algensindo, 2001.

Schilbrack, Kevin. Thinking Through Rituals: Philosophical Perspectives. New York and London: Routledge, 2004.

Schweder, Richard A dan Byron Good. Clifford Geertz by His Colleagues. London: The University of Chicago Press, 2005.

Suharno. "Inilah Nilai-nilai Shalat," artikel diakses pada 12 Maret 2020 dari https://www.republika.co.id/berita/dunia-islam/hikmah/12/06/03/m50q76-inilahnilainilai-shalat

Tago, Mahli Zainudin. "Agama dan Integrasi Sosial dalam Pemikiran Clifford Geertz," Jurnal Kalam VII, no. 1, (2013): h. 81.

Usmani, Ahmad Rofi. Kisah Para Pencari Nikmatnya Shalat. Bandung: Mizan Pustaka, 2015.

Wahyuni, Agama dan Pembentukan Struktur Sosial. Jakarta: Prenadamedia Group, 2018.

Wratsangko, Madto. Shalat Jadi Obat. Jakarta: Elex Media Komputindo, 2010. 